\title{
PENGARUH 5C (CHARACTER, CAPACITY, CAPITAL, COLLATERAL, DAN CONDITION OF ECONOMY) TERHADAP PEMBERIAN KREDIT (Studi Kasus Koperasi Pegawai Telkom Purwokerto)
}

\author{
Regilia Asri Cahyaningtyas ${ }^{1}$, Akhmad Darmawan ${ }^{2}$ \\ Program Studi Manajemen \\ Fakultas Ekonomi dan Bisnis \\ Universitas Muhammadiyah Purwokerto \\ regiliaasri@gmail.com
}

\begin{abstract}
ABSTRAK
Penelitian ini bertujuan untuk mengetahui pengaruh character, capcity, capital, collateral dan condition terhadap pemberian kredit pada Koperasi Pegawai Telkom Purwokerto. Jumlah sampel pada penelitian ini sebanyak 35 responden. Variabel bebas (independent variable) yang digunakan dalam penelitian ini adalah character (X1), capacity (X2), capital (X3), collateral (X4) dan condition of Economy (X5). Variabel terikat (dependent variable) yang digunakan dalam penelitian ini adalah pemberian kredit. Pengujian hipotesis dilakukan dengan uji regresi. Hasil penelitian menunjukkan bahwa character, capacity, capital, collateral dan condition of economy secara parsial tidak mempunyai pengaruh terhadap pemberian kredit.
\end{abstract}

Kata kunci : character, capacity, capital, collateral, condition of economy dan pemberian kredit.

\section{ABSTRACT}

This study aims to determine the influence of character, capcity, capital, collateral and conditions on the provision of credit on Telkom Employees Cooperative Purwokerto. The number of samples in this study were 35 respondents. The independent variables used in this research are character (X1), capacity (X2), capital (X3), collateral (X4) and condition of economy (X5). The dependent variable used in this research is crediting. Hypothesis testing is done by regression test. The results show that the character, capacity, capital, collateral and condition of economy partially have no effect on the provision of credit.

Keywords : character, capacity, capital, collateral, condition of economy and credit providing.

\section{PENDAHULUAN}

Perkembangan dunia perbankan yang telah terlihat semakin kompleks, dengan berbagai produk dan sistem usaha dalam berbagai keunggulan kompetitif. Keadaaan yang kompleks ini telah menciptakan suatu sistem dan pesaing baru dalam dunia perbankan, bukan hanya persaingan antar bank tetapi juga antara bank dengan lembaga keuangan. Sektor perbankan menjadi salah satu factor yang memegang peranan karena berfungsi sebagai penghimpun dan penyalur dana melalui penciptaan produk yang beraneka ragam untuk ditawarkan kepada masyarakat yang ingin menggunakan jasa perbankan. (Siska, 2012)

Kredit merupakan aktiva produktif yang memberikan pendapatan utama. Semakin besar tingkat atau proporsi kredit dari keseluruhan pinjaman, maka semakin besar pula jumlah investasi kredit yang dimiliki perbankan. Dengan 
besarnya volume pinjaman kredit setiap tahunnya, berarti bank tersebut harus menyediakan investasi yang lebih besar lagi. Adanya pinjaman kredit yang dilakukan, dapat mengurangi kemungkinan risiko seperti munculnya biaya penambahan pegawai dan pengurusan administrasi. Saat semua masalah ini bermunculan, secara langsung akan menghambat kelancaran operasional yang harus dicapai perusahaan. Oleh karena itu, sebelum melakukan pemberian kredit, pihak perbankan harus memperhatikan unsur $5 \mathrm{C}$ (The Five of Credit), yaitu character, capacity, capital, collateral and condition.

\section{TINJAUAN PUSTAKA}

\section{Kredit}

Kredit berasal dari bahasa Yunani, "credere", yang berarti kepercayaan. Dengan demikian istilah kredit memiliki arti khusus, yaitu meminjamkan uang (atau penundaan pembayaran). Apabila masyarakat membeli secara kredit, maka hal itu berarti si pembeli tidak harus membayarnya pada saat itu juga ( Manurung, 2015 )

\section{Character}

Character (Watak) Perusahaan mencari data tentang kepribadiaan atau watak calon debitur seperti kebiasaan-kebiasaan, sifat, cara hidup, keadaan keluarga, hobi, dan hubungan sosial dengan masyarakat. Perusahaan melakukan penilaian untuk mengetahui apakah pemohon kredit ada kemauan membayar hutang jika permohonannya terkabul dan kemungkinan atau probabilitas dari debitur secara jujur berusaha memenuhi kewajiban. (Yulianto, 2016 ). Character berpengaruh positif signifikan terhadap keputusan kredit, artinya apabila character semakin meningkat, maka keputusan kredit semakin meningkat.

\section{Capacity}

Capacity (kapasitas) usaha yang dimiliki calon debitur harus dinilai apakah mampu untuk berkembang, sehingga mampu melunasi kewajibannya. (Oka, Purnawati, dan Sinarwati, 2015). Capacity berpengaruh positif terhadap keputusan kredit, artinya apabila capasity semakin meningkat, maka keputusan kredit semakin meningkat. Semakin baik capacity, maka semakin baik pula keputusan kredit yang diberikan oleh bank atau bank, sebab pihak bank yakin kemampuan debitur dalam mengembalikan kredit yang diberikan.

\section{Capital}

Capital (Modal) Penilaian modal diukur dari posisi keuangan perusahaan secara umum. Penilaian terhadap permodalan tidak hanya dilihat dari besar kecilnya modal tersebut melainkan juga bagaimana modal tersebut ditempatkan oleh pengusaha. Perusahaan akan menilai apakah pengaturan modal berjalan secara efektif sehingga kredit digunakan untuk membiayai kekurangan usaha debitur. Selain itu untuk mengetahui besar modal sendiri yang tertanam pada usahanya dan berapajumlah yang berasal dari pihak lain agar tanggung jawab terhadap kredit dari bank proporsional. (Yulianto, 2016 ). Capital berpengaruh positif signifikan terhadap keputusan kredit, artinya apabila capital semakin meningkat, maka keputusan kredit semakin meningkat. 


\section{Collateral}

Collateral (Agunan/Jaminan) yang dimiliki debitur/calon debitur. Jaminan hendaknya melebihi jumlah kredit yang diberikan. Jaminan juga harus diteliti keabsahan dan kesempurnaannya, sehingga jika terjadi suatu masalah, maka jaminan yang dititipkan akan dapat dipergunakan secepat mungkin. Agunan sangat penting karena menjadi second way out apabila terjadi masalah pada kredit debitur. (Oka, Purnawati, dan Sinarwati, 2015 ). Colleteral berpengaruh positif signifikan terhadap keputusan kredit, artinya apabila colleteral semakin meningkat, maka keputusan kredit semakin meningkat.

\section{Condition of Economy}

Condition (Kondisi) perekonomian, politik, sosial, dan budaya juga patut menjadi pertimbangan terkait dengan jenis usaha calon debitur. Jika perekonomian sedang tumbuh pesat, dan usaha calon debitur masuk dalam kategori pertumbuhan, maka akan lebih mudah untuk diberikan kredit. (Oka, Purnawati, dan Sinarwati, 2015 ). Condition of economic berpengaruh positif signifikan terhadap keputusan kredit, artinya apabila condition of economi semakin meningkat, maka keputusan kredit semakin meningkat.

Berdasarkan penjelasan diatas, maka dapat digambarkan kerangka pemikiran sebagai berikut:

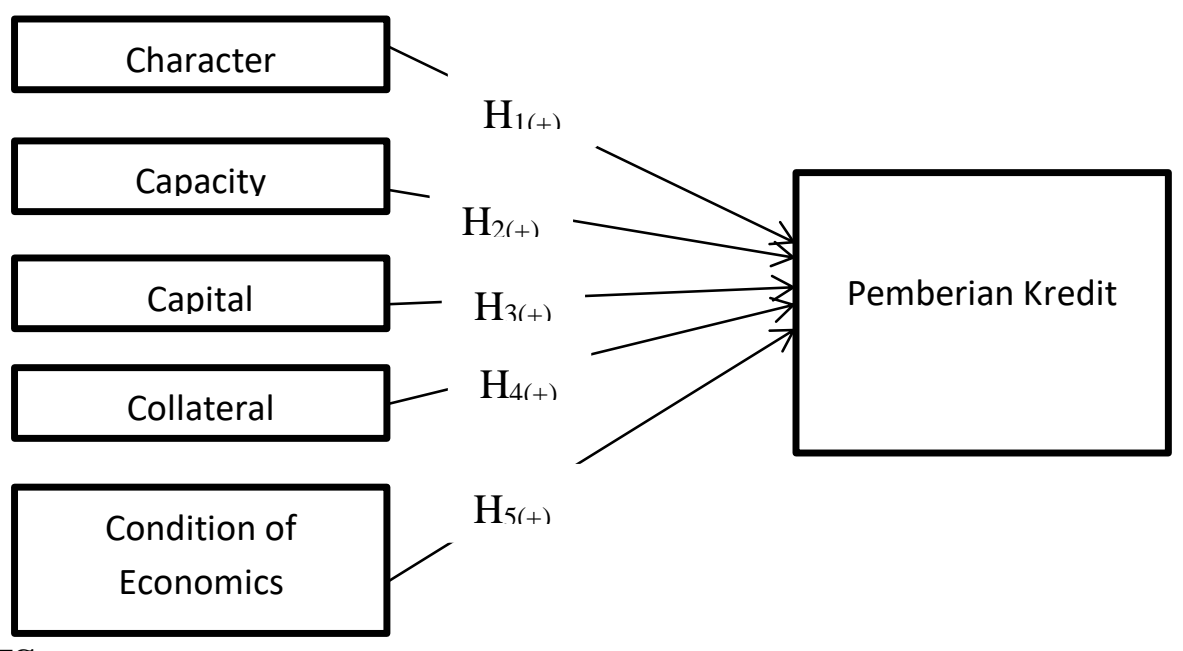

\section{HIPOTESIS}

Atas pertimbangan masalah maka hopitesis penelitian ini adalah:

$\mathrm{H}_{1} \quad$ : Character berpengaruh terhadap pemberian kredit.

$\mathrm{H}_{2} \quad$ :Capacity berpengaruh terhadap pemberian kredit

$\mathrm{H}_{3}$ : Capital berpengaruh terhadap pemberian kredit

$\mathrm{H}_{4}$ : Collateral berpengaruh terhadap pemberian kredit

$\mathrm{H}_{5}$ : Condition of Economy berpengaruh terhadap pemberian kredit.

\section{METODOLOGI PENELITIAN}

Jenis penelitian yang digunakan adalah penelitian kuantitatif. Penelitian kuantitatif adalah jenis penelitian yang menghasilkan penemuan-penemuan yang dapat dicapai dengan menggunakan prosedur-prosedur statistik atau cara-cara lain dari pengukuran. Pendekatan kuantitatif memusatkan perhatian pada gejala yang mempunyai karakteristik tertentu didalam kehidupan manusia yang dinamakan sebagai variabel ( Ghozali,2016:33). 
Dalam penelitian ini populasi yang digunakan adalah Koperasi Pegawai Telkom (KOPEGTEL) di Purwokerto. Sedangkan sampel yang dipakai dalam penelitian ini adalah Nasabah dan Ahli Kredit dengan menggunakan metode random sampling dengan Table Isaac dan Michael dengan jumlah 35 responden.

Untuk menguji hasil kuisioner menggunakan uji validitas dan reliabilitas. uji asumsi klasik (normalitas, heterokedastisitas dabnmultikolonieritas) dan uji regresi linier berganda. Sedangkan untuk menguji hipotesis dengan menggunakan koefesien determinasi, dan $\mathrm{t}$ (parameter) individual.

\section{HASIL DAN PEMBAHASAN}

\section{Hasil Uji Validitas dan Reliabilitas}

Uji validitas digunakan untuk mengukur sah atau valid tidaknya suatu kuesioner. Suatu kuesioner dikatakan valid jika pertanyaan pada kuesioner mampu mengungkkapkan sesuatu yang akan diukur oleh kuesioner tersebut (Ghozali, 2016:52). Penelitian ini menggunakan 7 penyataan pada variabel Character dan valid semua, Capacity terdapat 6 pernyataan, Capital sebanyak 7 pernyataan , Collateral 5 pernyataan, Condition of Economy 5 pernyataan dan valid semua serta yang terakhir pemberian kredit 5 pernyataan dan valid semua.

Uji reliabilitas sebenarnya adalah alat untuk mengukur suatu kuesioner yang merupakan indikator dari variabel atau konstruk. Suatu kuesioner dikatakan reliabel atau handal jika jawaban seorang terhadap pertanyaan adalah konsisten atau stail dari waktu ke waktu. Suatu variabel dikatakan reliabel jika memberikan nilai Cronbachs Alpha > 0,70 (Ghozali, 2016:48). Dari uji reliabilitas , semua variabel berasada pada cronbachs alpha $>0,70$ sehingga semua variabel reliabel.

\section{Hasil Uji Asumsi Klasik Uji Multikolonieritas}

Berdasarkan pada hasil output SPSS uji multikolonieritas menunjukkan bahwa nilai tolerance masing-masing variabel tidak ada yang dibawah 0,10 (nilai tolerance Character sebesar 0,646, Capacity sebesar 0,113, Capital sebesar 0,172, Collateral sebesar 0,183 dan Condituon of Economy sebesar 0,121), begitu juga dengan nilai VIF tidak ada yang diatas 10 (nilai VIF Character sebesar 1,548, Capacity sebesar 8,863, Capital sebesar 5,823, Collateral sebesar 5,540 dan Condituon of Economy sebesar 8,237). Dari data tersebut maka data penelitian ini bebas dari asumsi multikolinearitas.

\section{Uji Heteroskesdatisitas}

Berdasarkan pada hasil output SPSS uji heteroskesdastisitas dapat diketahui bahwa nilai signifikansi dari variabel Character sebesar 0,174, Capacity sebesar 0,342, Capital sebesar 0,665, Collateral sebesar 0,537 dan Condition of Economy sebesar 0,519. Dari kelima variabel tersebut, nilai signifikansinya diatas 0,05 , maka dapat disimpulkan bahwa data yang digunakan tidak terjadi heteroskedastisitas.

\section{Uji Normalitas}

Berdasarkan pada hasil output SPSS uji Kolmogrov Smirnov nilai Asym.Sig sebesar 0,094, nilai tersebut memenuhi ketentuan sig. (p) >0,05 (level of signification). Hal ini berarti bahwa data residual berdistribusi normal. 


\section{Hasil Uji Hipotesis}

\section{Uji Analisis Regresi Linier Berganda}

Berdasarkan hasil analisis regresi tersebut di atas, dapat disusun persamaan regresi sebagai berikut:

$$
\begin{aligned}
\mathrm{Y} & =\alpha+\beta_{1} \mathrm{X}_{1}+\beta_{2} \mathrm{X}_{2}+\beta_{3} \mathrm{X}_{3}+\beta_{4} \mathrm{X}_{4}+\beta_{5} \mathrm{X}_{5}+\mathrm{e} \\
& =18.434+0,235 \mathrm{X}_{1}+(-0,619) \mathrm{X}_{2}+(-0,160) \mathrm{X}_{3}+0,290 \mathrm{X}_{4}+0,474 \mathrm{X}_{5}+\mathrm{e}
\end{aligned}
$$

Persamaan regresi tersebut diatas dapat dijelaskan sebagai berikut:

$\alpha=$ Nilai konstanta $(\alpha)$ menunjukkan nilai positif variabel independen (Character, Capacity, Capital, Collateral, dan Condition of Economy). Bila variabel independen naik atau berpengaruh dalam satu satuan, maka variabel pemberian kredit akan naik atau terpenuhi.

$\beta_{1} \quad=$ Nilai koefisien regresi variabel Character menunjukkan nilai positif sebesar 0,235 meyatakan bahwa setiap peningkatan Character sebesar satu satuan maka menyebabkan keputusan pembelian meningkat sebesar 0,235 satuan dengan asumsi variabel lain tetap.

$\beta_{2}=$ Nilai koefisien regresi variabel Capacity menunjukkan nilai Negative sebesar -0,619 bahwa setiap peningkatan Capacity sebesar 1 satuan maka tidak menyebabkan minat beli meningkat sebesar -0,619 satuan dengan asumsi variabel lain tetap.

$\beta_{3}=$ Nilai koefisien regresi variabel Capital menunjukkan nilai Negative sebesar -0,160 bahwa setiap peningkatan Capital sebesar 1 satuan maka tidak menyebabkan minat beli meningkat sebesar $-0,160$ satuan dengan asumsi variabel lain tetap.

$\beta_{4} \quad=$ Nilai koefisien regresi variabel Collateral menunjukkan nilai positif sebesar 0,290 bahwa setiap peningkatan Collateral sebesar 1 satuan maka menyebabkan keputusan pembelian meningkat sebesar 0,290 satuan dengan asumsi variabel lain tetap.

$\beta_{5}=$ Nilai koefisien regresi variabel Condition of Economy menunjukkan nilai positif sebesar 0,474 bahwa setiap peningkatan Condition of Economy sebesar 1 satuan maka menyebabkan keputusan pembelian meningkat sebesar 0,474 satuan dengan asumsi variabel lain tetap.

e $\quad=$ Standar kesalahan (error).

\section{Uji Koefisien Determinan $\left(\mathbf{R}^{2}\right)$}

Berdasarkan hasil Output SPSS Uji R Square dapat dilihat bahwa nilai koefisisen determinasi $\left(\mathrm{R}^{2}\right)$ sebesar 0,096 sama dengan 9,6\% Angka tersebut mengandung arti bahwa Character, Capacity, Capital, Collateral, dan Condition of Economy. Sedangkan sisanya 90,4\% dijelaskan oleh variabel lain yang tidak termasuk dalam model. Angka yang mendekati 0 manyatakan bahwa semakin lemah pengaruh $5 \mathrm{C}$ terhadap pemberian kredit

\section{Uji t}

\section{Hipotesis Pertama}

Berdasarkan tabel 4.13 dapat diketahui bahwa hasil uji t untuk variabel Character $\left(\mathrm{X}_{1}\right)$ diperoleh nilai t hitung 1,395 sedangkan $\mathrm{t}$ tabel sebesar 2,048. Hal ini berarti $t_{\text {hitung }}<t_{\text {tabel }}$ sedangkan signifikansi 0,174 lebih dari 0,05. Oleh karena nilai $t_{\text {hitung }}<t_{\text {tabel }}(1,395<2,048)$ artinya secara parsial Character tidak berpengaruh terhadap Pemberian Kredit, sehingga hipotesis ditolak dan Ho diterima. 


\section{Hipotesis Kedua}

Berdasarkan tabel 4.13 dapat diketahui bahwa hasil uji t untuk Capacity $\left(\mathrm{X}_{2}\right)$ diperoleh nilai $\mathrm{t}$ hitung $-0,967$ sedangkan $\mathrm{t}$ tabel sebesar 2,048. Hal ini berarti $t_{\text {hitung }}<t_{\text {tabel }}$ sedangkan signifikansi 0,342 lebih dari 0,05. Oleh karena nilai $t_{\text {hitung }}<$ $t_{\text {tabel }}(-0,967>2,048)$ artinya secara parsial Capacity tidak berpengaruh terhadap Pemberian Kredit, sehingga hipotesis ditolak dan Ho diterima.

\section{Hipotesis Ketiga}

Berdasarkan tabel 4.13 dapat diketahui bahwa hasil uji t untuk Capital $\left(\mathrm{X}_{3}\right)$ diperoleh nilai t hitung $-0,437$ sedangkan $t$ tabel sebesar 2,048. Hal ini berarti $\mathrm{t}_{\text {hitung }}<\mathrm{t}_{\text {tabel }}$ sedangkan signifikansi 0,665 lebih dari 0,05. Oleh karena nilai $\mathrm{t}_{\text {hitung }}<$ $t_{\text {tabel }}(-0,437>2,048)$ artinya secara parsial Capital tidak berpengaruh terhadap Pemberian Kredit, sehingga hipotesis ditolak dan Ho diterima.

\section{Hipotesis Keempat}

Berdasarkan tabel 4.13 dapat diketahui bahwa hasil uji t untuk Collateral $\left(\mathrm{X}_{4}\right)$ diperoleh nilai t hitung 0,625 sedangkan t tabel sebesar 2,048. Hal ini berarti $t_{\text {hitung }}<t_{\text {tabel }}$ sedangkan signifikansi 0,537 lebih dari 0,05. Oleh karena nilai $t_{\text {hitung }}<$ $t_{\text {tabel }}(0,625>2,048)$ artinya secara parsial Collateral tidak berpengaruh terhadap Pemberian Kredit, sehingga hipotesis ditolak dan Ho diterima.

\section{Hipotesis Kelima}

Berdasarkan tabel 4.13 dapat diketahui bahwa hasil uji t untuk Condition of Economy $\left(\mathrm{X}_{5}\right)$ diperoleh nilai t hitung 0,653 sedangkan $\mathrm{t}$ tabel sebesar 2,048. Hal ini berarti $t_{\text {hitung }}<t_{\text {tabel }}$ sedangkan signifikansi 0,519 lebih dari 0,05. Oleh karena nilai $t_{\text {hitung }}<\mathrm{t}_{\text {tabel }}(0,653>2,048)$ artinya secara parsial Condition of Economy tidak berpengaruh terhadap Pemberian Kredit, sehingga hipotesis ditolak dan Ho diterima.

\section{SIMPULAN DAN SARAN}

\section{Kesimpulan}

Penelitian ini bertujuan untuk mengetahui pengaruh Character, Capacity, Capital, Collateral, dan Condition of Economy terhadap Pemberian Kredit pada Koperasi Pegawai Telkom di Purwokerto. Berdasarkan analisis data dan pembahasan yang telah dilakukan maka dapat ditarik kesimpulan sebagai berikut:

1. Character tidak berpengaruh terhadap keputusan pengambilan kredit.

2. Capacity tidak berpengaruh terhadap keputusan pengambilan kredit

3. Capital tidak berpengaruh terhadap keputusan pengambilan kredit.

4. Collateral tidak berpengaruh terhadap keputusan pengambilan kredit.

5. Condition of Economy tidak berpengaruh terhadap keputusan pengambilan kredit.

Keterbatasan dalam penelitian ini adalah sebagai berikut:

1. Sampel yang digunakan dalam penelitian ini hanya 35 responden, sehingga tidak menutup kemungkinan akan diperoleh hasil yang berbeda jika menggunakan sampel yang lebih banyak. 
2. Penelitian ini hanya menerapkan metode survei melalui kuesioner, penelitian ini tidak melakukan metode wawancara, sehingga kesimpulan yang dikemukakan hanya berdasarkan pada data yang terkumpul melalui instrument secara tertulis.

\section{Saran}

Peneliti selanjutnya hendaknya memperbanyak sampel penelitian, tidak hanya 35 responden saja namun bisa lebih dari 35 responden agar semakin mengetahui karakteristik suatu populasi dari banyaknya sampel yang mewakili populasi tersebut.

\section{DAFTAR PUSTAKA}

Ghozali, Imam. 2016. Aplikasi Analisis Multivariate dengan Program IBMSPSS 21 Update PLS Regresi. Edisi 8.Semarang,Universitas Diponegoro.

Ghozali, Imam. 2016. Desain Penelitian Kuantitatif \& Kualitatif Untuk Akutansi, Bisnis dan Ilmu Sosial Liannya. Yoga Pratama. Semarang

Ikhwan, Nuzul, Raymond, dan Dian Lestari Siregar. 2017. Analysis Of Implementation 5c Aspects On Banking Credit Distribution In Batam. Jurnal AKRAB JUARA Volume 1 Nomor 1 Edisi Agustus 2016 (56-69)

Indonesia, Ikatan Bankir. 2015. Manajemen Risiko 1. Jakarta: PT. Gramedia Pustaka Utama

Kasmir. 2009. Bank dan Lembaga Keuangan Lainnya. Jakarta: PT. Raja Grafindo Kasmir. 2012. Bank dan Lembaga Keuangan Lainnya. Jakarta: PT. Raja Grafindo Manurung, Herta. 2015. Pengaruh Character, Capacity, Capital, Collateral Dan Condition Terhadap Pemberian Kredit Pada Pt. Bri Unit Siborong-Borong. Jurnal ilmiah "INTEGRITAS" Vol.1 No. 1 Januari 2015

Monulandi, Maria Marlyn, Joachim N. K. Dumais, dan Lyndon R. J. Pangemanan. 2016. Persepsi Nasabah Terhadap Penerapan Prinsip 5c Dalam Penyaluran Kredit Usaha Rakyat (Kur) Oleh Pt. Bank Rakyat Indonesia (Persero), Tbk Unit Tombatu, Minahasa Tenggara. Agri-SosioEkonomi Unsrat, ISSN 1907- 4298 , Volume 12 Nomor 2A, Juli 2016 : 303 - 314

Maristiana, Siska, Hartono, Agus Supriyanto. 2017. Pengaruh Analisis 5 C (Character, Capacity, Capital, Colleteral And Condition) Dalam Pemberian Kredit Di Pt. Bank Bri Unit Indraprasta. Jurnal of Accounting, Vol. 3 N0. 3, Maret 2017.

Oka, Komang Wulan Lestari, I Gusti Ayu Purnamawati, Ni Kadek Sinarwati. 2015. Pengaruh Dana Pihak Ketiga, Penilaian 5c Kredit, Dan Kualitas Kredit Terhadap Keputusan Pemberian Kredit Di Pt. Bank Pembangunan Daerah Bali Cabang Singaraja. e-Journal S1 Ak Universitas Pendidikan Ganesha Jurusan Akuntansi Program S1 (Volume 3, No. 1 Tahun 2015)

Sugiyono. 2014.Metode Penelitian kuantitatif, Kualitatif dan Kombinasi (Mixed Methd). Bandung: Alfabeta

Sujarweni,V. Wiratna. 2015. Metodologi Penelitian BISNIS \& EKONOMI. Yogyakarta: PUSTAKABARUPRES.

Yulianto, Alex. 2016. Analisis Penerapan 5 C Dalam Pemberian Kredit Konsumtif Pada Pt. Adira Dinamika Multifinance Cabang Nangka Pekanbaru. JOM FISIP Vol. 3 No. 1 - Februari 2016. 